\title{
Comparative Study of Use of Mifepristone and Misoprostol Regimen with Misoprostol Alone For Induction of Labour in Term Pregnancy
}

\author{
Dr. Sonam Jindal ${ }^{1 *}$, Dr. Savita Rani Singhal ${ }^{2}$
}

${ }^{1}$ Senior Resident, Department of Obstetrics and Gynaecology, ESIC medical college and hospital, Faridabad, Haryana, 121001, India

${ }^{2}$ Professor and Unit Head, Department of Obstetrics and Gynaecology, Pt. B.D. Sharma Postgraduate Institute of Medical Sciences, Rohtak, Haryana, 124001, India

DOI: $10.36347 /$ sjams.2020.v08i05.013

| Received: 21.04.2020 | Accepted: 07.05.2020 | Published: 14.05.2020

*Corresponding author: Dr. Sonam Jindal

Abstract Original Research Article

Background: Mifepristone when is combined with misoprostol for induction of labour at term, it has shown to decrease the dose, thus the side effects of misoprostol. Objective: The aim of our study was to compare the efficacy of mifepristone and misoprostol regimen with misoprostol alone for induction of labour at term. Material and method: A total of 100 pregnant women with singleton pregnancy, cephalic presentation, gestational age of 37-41 weeks, Bishop score $\leq 6$ were enrolled at a tertiary care center in India and randomized into two groups alternately. Group I received $200 \mathrm{mg}$ of mifepristone orally on day one. Repeat Bishop score was done after 24 hours and if $\leq 6$ then $25 \mu \mathrm{g}$ of misoprostol was administered vaginally repeated at four hourly intervals upto maximum of six doses. Group II received $25 \mu \mathrm{g}$ of misoprostol per vaginally at four hourly intervals upto maximum of six doses. In both the groups Bishop score was $\leq 6$ after six doses, then induction attempt was considered as failure and was taken for caesarean section. Results: There was significant difference in the total no. of doses required for vaginal delivery $(1.42 \pm 1.35 \mathrm{vs}$ $2.66 \pm 1.03 \mathrm{p}<0.001)$, misoprostol induction to favourable bishop score interval $(8.07 \pm 0.85$ and $8.41 \pm 0.58$ hours $\mathrm{p}<0.01)$, misoprostol induction to delivery interval $(8.46 \pm 4.60$ vs $12.13 \pm 4.23$ hours, $\mathrm{p}<0.001)$ between two groups. Conclusion: Administration of mifepristone before misoprostol appears to be safe and better than misoprostol alone as there is significant improvement in Bishop score after 24 hours of mifepristone, reduction in number of doses of misoprostol required, shorter misoprostol induction to delivery interval and good number of vaginal deliveries within 24 hours without any requirement of misoprostol.

Keywords: Induction, Mifepristone, Misoprostol, Term.

Copyright @ 2020: This is an open-access article distributed under the terms of the Creative Commons Attribution license which permits unrestricted use, distribution, and reproduction in any medium for non-commercial use (NonCommercial, or CC-BY-NC) provided the original author and source are credited.

\section{INTRODUCTION}

Induction of labour is an important tool in today's obstetrics. It is a life saving procedure for mother or baby or both when physiological processes of labour become unnatural. Induction of labour is the process of artificially initiating labour for the purpose of fetal and placental delivery. In developed countries $25 \%$ of all deliveries at term now involve induction of labour [1].

Misoprostol (Prostaglandin E1) is a prostaglandin analogue used in obstetrics for cervical ripening and induction of labour and is administered either transvaginally, orally or sublingually in multiple repeated doses. It has serious side effects like uterine hypoerstimulation with fetal heart changes, tachysystole, meconium stained liquor, and uterine rupture $[2,3]$. It is contraindicated in previously scarred uterus and grand multipara. These side effects are dose dependent and may be minimized if we combine misoprostol with other methods which reduce its dose.

Mifepristone is a 19 non-steroid which has greater affinity for progesterone receptors than progesterone itself. It has potent anti-progestogenic, anti-glucocorticoid and weak anti-androgenic effect [4]. It increases the sensitivity of uterus to the actions of prostaglandins. It is characterized by rapid absorption and has long half life of 25-30 hours.

Mifepristone has been used in conjunction with misoprostol for ripening of cervix and induction of labour in term pregnancy as early as 1996 [5]. According to Cochrane Pregnancy and Childbirth Group's trial of May 2009 which included ten trials and was carried out on 1108 women, mifepristone treated women were more likely to be in labour or to have a favourable cervix at 48 hours as compared to placebo. This study suggested that mifepristone is better than 
placebo in reducing the likelihood of caesarean sections being performed for failed induction [6].

In this study, we hypothesized that mifepristone when followed by misoprostol for induction of labour in term live pregnancy has better response than misoprostol used alone. Although theoretical evidence is available in this context, no consensus has yet been reached in the literature that mifepristone followed by misoprostol combination has better efficacy than misoprostol significantly or not. So, present study was planned to compare the efficacy of mifepristone and misoprostol with misoprostol alone for induction of labour in term pregnancy.

\section{Material And Methods}

The present study was conducted on 100 women with singleton pregnancy, cephalic presentation, gestational age of $37-41$ weeks, Bishop score $\leq 6$ admitted in the labour room at a tertiary care centre in India and randomized into two groups alternately.

- Group I comprised of 50 pregnant women who received mifepristone followed by misoprostol for induction of labour.

- Group II will comprised of 50 pregnant women who received misoprostol alone.

Women with scarred uterus, contraindications for vaginal delivery, active renal or liver disease, grand multipara, women requiring urgent induction of labour, those on steroid therapy or who were hypersensitive to drugs were excluded from the study.

After taking written informed consent, the detailed history of women, general physical, systemic and obstetrical examination including per vaginal examination was carried out. Bishop score was assessed as per modified Bishop's pelvic scoring system [7].

All women were subjected to the investigations namely haemoglobin, blood group $\mathrm{ABO}$ and $\mathrm{Rh}$ typing, HIV, blood sugar, complete urine examination and ultrasonography if not done earlier.

Women in Group I received $200 \mathrm{mg}$ of mifepristone orally on day one. Repeat Bishop score was done after 24 hours and if $\leq 6$ then $25 \mu \mathrm{g}$ of misoprostol was administered vaginally and doses were repeated at four hourly intervals upto maximum of six doses. If Bishop score was $\leq 6$ after six doses of misoprostol then the induction attempt was considered as failure and she was taken up for caesarean section.

Group II received $25 \mu \mathrm{g}$ of misoprostol per vaginally at four hourly intervals upto maximum of six doses. If Bishop score was $\leq 6$ after six doses, then induction attempt was considered as failure and women was taken up for caesarean section. In both the groups, if Bishop score became $>6$ during any of the assessment then labour augmentation was done if required by oxytocin.

The primary outcome measures were number of misoprostol doses required, need of caesarean section, induction failure while secondary outcomes variables were meconium stained liquor, APGAR score, admission in NICU and NICU stay.

At the end of the study data was compiled and analyzed using chi-square test. A p value of $<0.05$ was considered significant.

\section{RESULTS}

The results are shown in table 1-4. Age, parity, period of gestation and initial Bishop score was comparable in both the groups $(p>0.05)$. Regarding indication of induction of labour, the majority of the inductions in each group i.e. $54 \%$ in group I and $62 \%$ in group II were done for postdatism. In group I of our study other indications were oligohydroamnios (16\%), $\mathrm{Rh}$ negative pregnancy (16\%), preeclampsia (10\%), intra uterine growth retardation $(2 \%)$ and cholestasis of pregnancy $(2 \%)$. Preeclampsia $(22 \%)$, Rh negative $(12 \%)$, oligohydroamnios $(4 \%)$ were other indications of induction in group II.

In group I, Bishop score after 24 hours of mifepristone induction was $5 \pm 2.09$ which was significantly higher than at the onset $(3.26 \pm 0.89)$ $(\mathrm{p}<0.001)$. In this group thirteen $(26 \%)$ women delivered vaginally after mifepristone administration without requiring misoprostol. Out of 13 , nine women delivered within 24 hours of mifepristone induction without requiring misoprostol and four women had favourable Bishop score at end of 24 hours of mifepristone. The mifepristone priming to delivery interval (IDI) was $29.03 \pm 9.62$ hours. Two women had caesarean section within 24 hours due to fetal distress.

Table-1: Demographic characteristics, period of gestation and the initial Bishop's score in two groups

\begin{tabular}{|l|l|l|l|}
\hline $\begin{array}{l}\text { Characteristic } \\
(\text { Mean } \pm \text { SD) }\end{array}$ & $\begin{array}{l}\text { Group I } \\
\mathbf{n = 5 0}\end{array}$ & $\begin{array}{l}\text { Group II } \\
\mathbf{n = 5 0}\end{array}$ & $\begin{array}{l}\text { Significance } \\
\text { P value }\end{array}$ \\
\hline Age in years & $23.46 \pm 2.61$ & $24.38 \pm 3.31$ & 0.126 \\
\hline Parity & $0.56 \pm 0.70$ & $0.34 \pm 0.55$ & 0.213 \\
\hline Period of gestation in weeks & $39.5 \pm 0.95$ & $39.72 \pm 0.67$ & 0.185 \\
\hline Initial Bishop's score & $3.26 \pm 0.89$ & $3.34 \pm 0.71$ & 0.623 \\
\hline
\end{tabular}


Table-2: Doses of misoprostol required and the different time intervals (hours) in two groups

\begin{tabular}{|l|l|l|l|}
\hline Characterstic (Mean \pm SD) & $\begin{array}{l}\text { Group I } \\
(\mathbf{n})\end{array}$ & $\begin{array}{l}\text { Group II } \\
(\mathbf{n})\end{array}$ & $\begin{array}{l}\text { Significance } \\
\text { P value }\end{array}$ \\
\hline Total number of doses required for vaginal delivery & $\begin{array}{l}1.42 \pm 1.35 \\
(\mathrm{n}=40)\end{array}$ & $\begin{array}{l}2.66 \pm 1.03 \\
(\mathrm{n}=39)\end{array}$ & $<0.001$ VHS \\
\hline Misoprostol induction to favourable bishop score (>6) interval (hours) & $\begin{array}{l}8.07 \pm 0.85 \\
(\mathrm{n}=28)\end{array}$ & $\begin{array}{l}8.41 \pm 0.58 \\
(\mathrm{n}=43)\end{array}$ & $<0.01 \mathrm{HS}$ \\
\hline Misoprostol induction to delivery interval (hours) & $\begin{array}{l}8.46 \pm 4.60 \\
(\mathrm{n}=31)\end{array}$ & $\begin{array}{l}12.13 \pm 4.23 \\
(\mathrm{n}=39)\end{array}$ & $<0.001$ \\
\hline
\end{tabular}

Table-3: Mode of delivery, failed induction and need for oxytocin augmentation in two groups

\begin{tabular}{|l|l|l|l|}
\hline Characteristic & Group I n (\%) & Group II n (\%) & $\begin{array}{l}\text { Significance } \\
\text { P value }\end{array}$ \\
\hline Vaginal delivery & $39(78 \%)$ & $38(76 \%)$ & 0.970 \\
\cline { 1 - 3 } Caesarean delivery & $10(20 \%)$ & $11(22 \%)$ & \\
\hline Failed induction & $0(0 \%)$ & $1(2 \%)$ & 0.590 \\
\hline Need for oxytocin augmentation & $18(36 \%)$ & $24(48 \%)$ & 0.224 \\
\hline
\end{tabular}

Table-4: Fetal outcome in two groups

\begin{tabular}{|l|l|l|l|l|}
\hline \multicolumn{2}{|l|}{ Apgar score } & $\begin{array}{l}\text { Group I } \\
\text { n \% }\end{array}$ & $\begin{array}{l}\text { Group II } \\
\text { n \% }\end{array}$ & \multirow{2}{*}{ 'p' value } \\
\hline \multirow{4}{*}{ At 5 min } & $<4$ & 0 & 0 & 0.691 \\
\cline { 2 - 4 } & $4-7$ & $2(4 \%)$ & $4(8 \%)$ & \\
\cline { 2 - 4 } & $>7$ & $48(96 \%)$ & $46(92 \%)$ & \\
\cline { 2 - 4 } & Mean \pm SD & $8.7 \pm 0.67$ & $8.76 \pm 0.82$ & \\
\hline \multicolumn{2}{|l|}{ Meconium stained liquor } & $6(12 \%)$ & $7(14 \%)$ & 0.766 \\
\hline NICU Admission & $3(6 \%)$ & $4(8 \%)$ & 0.695 \\
\hline \multicolumn{2}{|l|}{ Mean NICU stay (days) } & $2.33 \pm 1.52$ & $2 \pm 1.41$ & 0.263 \\
\hline
\end{tabular}

\section{DISCUSSION}

Induction of labour is a common obstetric intervention, performed when the perceived risk to the mother or fetus associated with continuation of the pregnancy are greater than those associated with birth. Mifepristone, an antiprogestin, is a potential method of inducing labour in late pregnancy. When it is combined with misoprostol for induction of labour at term, it has shown to decrease the dose, thus the side effects of misoprostol.

The most common indication for labour induction in the present study was postdated pregnancy, which constituted $54 \%$ and $62 \%$ in group I and group II respectively. In the study by Mandade K 60\% and 80\% of women with postdated pregnancy were induced in mifepristone and misoprostol combination group and misoprostol only group respectively [8].

In this study, the mean initial Bishop score of women was $3.26 \pm 0.89$ and $3.34 \pm 0.71$ in the group I and group II respectively. In the study conducted by Fathima $\mathrm{S}$ et al., the preinduction Bishop score was $2.32 \pm 0.76$ in mifepristone group and $2.56 \pm 0.64$ in the dinoprostone group [9]. In the present study mean Bishop score after $24 \mathrm{hrs}$ of mifepristone administration was found to be $5 \pm 2.09$ and it was significantly higher than at onset $(\mathrm{p}<0.001)$. Same was observed by Yelliker $\mathrm{K}$ et al., [(5.0408 \pm 1.90$),(2.02 \pm 0.749)]$ in his study [10]. Study by Fathima $\mathrm{S}$ et al., showed the postinduction score assessed after 48 hours of mifepristone to be $7.25 \pm 1.75$ which was significantly higher than at the onset [9].

In present study $18 \%$ women delivered within 24 hours of mifepristone administration without requiring misoprostol which was almost comparable to study by Yelliker $\mathrm{K}$ et al., where $16 \%$ of women delivered within 24 hours [10]. Four women had favourable Bishop score (>6) after 24 hours of mifepristone induction. Similarly Wing et al., observed $19.5 \%$ vaginal deliveries in first 24 hours of mifepristone [11].

The number of doses of misoprostol required for attainment of favourable Bishop score were significantly less $[1.46 \pm 1.32$ (group I), $2.78 \pm 1.16$, (group II), (Table-2)] in present study. Similar results were shown in study by Mandade in which doses required in combination group $(1.4 \pm 0.8)$ were significantly less than in the group who required misoprostol only $(2.14 \pm 0.63)$ [8]. Yelikar K et al., observed mean dose of misoprostol required $40 \pm 27.2$ $\mu \mathrm{g}$ as compared to placebo $52 \pm 19.46 \mu \mathrm{g}$ [10].

Out of 50 inductions in each group, $18(36 \%)$ in group I and $24(48 \%)$ in group II required oxytocin augmentation (Table-3). This was comparable to trial by Cochrane Pregnancy and Childbirth Group carried out on 1108 women in 2009 which showed less 
requirement of oxytocin in mifepristone group than in placebo group (RR 0.80, $95 \%$ CI 0.66 to 0.97) [6]. Similar findings were seen in study by Fathima $\mathrm{S}$ et al., data showing less need for augmentation in mifepristone group compared to dinoprostone group [9].

Almost equal number of women underwent caesarean section in two groups [(group I 20\%, group II $(22 \%)]$ in our study and same was observed by Fathima S et al., (20\% in mifepristone group and $28 \%$ in dinoprostone group) [9]. The trial by Cochrane Pregnancy and Childbirth Group showed less caesarean section in mifepristone group compared to placebo group (RR 0.74, 95\% CI 0.60 to 0.92) [6].

The mean induction to delivery interval (IDI) of women in group I was $29.03 \pm 9.62$ hours and it was $32.46 \pm 4.60$ hours in 31 women who required misoprostol after mifepristone in group I. In a study by Fathima $\mathrm{S}$ et al., the mean IDI in mifepristone group was 32.00 hours and 65.25 hours in the 17 women of mifepristone group who required misoprostol for induction of labour [9]. The IDI was more in study by Fathima $\mathrm{S}$ et al., may be due to the reason that misoprostol was given after 48 hours of mifepristone and was repeated after every 8 hours as compared to the present study where misoprostol dose was given after 24 hours and repeated after every 4 hours. In Yelliker K et al., study mean IDI in mifepristone group was 31 hours [10].

The mean misoprostol IDI was significantly less in mifepristone misoprostol combination group $(8.06 \pm 4.60)$ as compared to $12.13 \pm 4.23$ in misoprostol only group (Table-2). Mandade et al also observed short IDI in mifepristone misoprostol combination group $(9.34 \pm 2.81)$ than in misoprostol only group $(10.94 \pm 2.81)$ but the difference was not statistically signifcant [8].

Fetal outcome was comparable in both the groups according to 5 minute Apgar score and NICU admissions (Table-5). Two (4\%) newborns in group I and four $(8 \%)$ in group II had Apgar score $<7$ at 5 minutes. In the study by Berkane in 2005 one out of 60 neonates and four out of 57 neonates in mifepristone and placebo group respectively had Apgar score $<7$ at 5 minutes [12].

\section{Conclusion}

To conclude administration of mifepristone before misoprostol is safe and better than misoprostol alone as there is significant improvement in Bishop score after 24 hours of mifepristone, reduction in number of doses of misoprostol required, shorter misoprostol induction to delivery interval and good number of vaginal deliveries within 24 hours without any requirement of misoprostol. There is no increased risk of caesarean section, failed induction or meconium stained liquor, NICU admissions when mifepristone is administered prior to misoprostol.

\section{REFERENCES}

1. WHO Recommendations for Induction of Labor. Guideline development group WHO. Geneva. WHO Press; 2011;4-36.

2. Abdel AH. Misoprostol for cervical ripening and induction of labour: RHL commentary. The WHO Reproductive Health Library; Geneva: World Health Organization, 2011.

3. Evidence-based Clinical Guideline Number 9. RCOG clinical Effectiveness Support Unit. Induction of Labour. London RCOG Press, 2001;1-90.

4. Heinkinheimo O. Clinical pharmacokinetics of mifepristone. Clin Pharmacokinet 1997;33:7-17.

5. Li L, Gao W, Chen S. Labour induction in women at term with mifepristone and misoprostol. Zhonghua Fu Chan KeZaZhi 1996;31:681-4.

6. Hapangama D, Neilson JP. Mifepristone for induction of labour. Cochrane Database of Sys Rev 2009;3:CD002865.

7. Bishop EH. Pelvic scoring for elective induction. Obstet Gynecol, 1964;24:266-8.

8. Mandade K, Bangal VB. A prospective comparative study to evaluate the efficacy and safety of mifepristone with misoprostol over misoprostol alone in induction of labour. Int $\mathrm{J}$ Reprod Contracept Obstet Gynaecol 2016;5:43218.

9. Fathima S, Nayak SR, Rao B, Praveena G, Shameem VPA. Mifepristone in induction of labour at term. Int $\mathbf{J}$ Pharm Biomed Res, 2013;4:164

10. Yelikar K, Deshpande S, Deshpande R, Lone D. Safety and efficacy of oral mifepristone in preinduction cervical ripening and induction of labour in prolonged pregnancy. J Obstet Gynaecol India, 2015;65:221-5

11. Wing D, Fassett M, Mishell DR. Mifepristone for preinduction cervical ripening beyond 41 weeks gestation: A randomized controlled trial. Obstet Gynaecol, 2000;96:543-8.

12. Berkane N, Verstraete L, Uzan S, Boog G, Maria B. Use of mifepristone to ripen the cervix and induce labour in term pregnancies. Am J Obstet Gynaecol, 2005;192:114-20. 